\title{
Three New Troglobitic Asellids from Western North America (Crustacea: Isopoda: Asellidae)
}

\author{
by
}

\author{
Thomas E. BOWMAN*
}

Troglobitic isopods of the family Asellidae, comprising about 42 species (Fleming, 1973), are widespread in the eastern United States, mostly in non-glaciated areas, but extending into some glaciated parts of Illinois and Indiana. To the west, troglobitic asellids range to central Kansas, Oklahoma and Texas. West of this area, if we exclude the 4 Mexican species of Mexistenasellus (Cole and Minckley, 1972; Magniez, 1972; Argano, 1973) which belong to a separate family, Stenasellidae (Henry and Magniez, 1968, 1970), only 2 troglobitic asellids are known from North America: Asellus californicus Miller (1933) from northern California and Conasellus pasquinii Argano (1972) from Veracruz state, México.

The 3 new species of western troglobitic asellids described herein extend the records of blind asellids in North America south to Chiapas state, Mexico, and north to central Alberta, Canada $\left(\mathrm{ca} .53^{\circ} \mathrm{N}\right)$, and add a second species from California. The new species from Chiapas is very similar to Conasellus pasquinii Argano (1972); the new asellids from Alberta and California show no close affinities with known species.

The generic status of North American species of Asellus is still unsettled. Henry and Magniez (1970) divided the species between Conasellus Stammer (1932) and Pseudobaicalasellus Henry and Magniez (1968) except $A$. tomalensis Harford and $A$. californicus Miller, which they believed to be closely related to far-eastern forms belonging to Asellus (Asellus) and Nipponasellus Matsumoto (1962). I have indicated that this is unlikely for $A$. tomalensis (see Bowman, 1974); the case of $A$. californicus will be discussed later in this paper.

Fleming (1973) presented arguments in favor of reducing both Pseudobaicalasellus and Conasellus to synonyms of Asellus. However, the taxonomic characters that Fleming analyzed to support his claim failed to include the basal and labial spurs (Bowman and Holmquist, 1975) and the catch-lobe, characters of the male pleopod 2 of Asellus that clearly separate it from American Asellidae except $A$. (Asellus) alaskensis Bowman and Holmquist.

While I consider Fleming's reduction of Conasellus to a synonym of Asellus unacceptable, I also feel that the assignment by Henry and Magniez of all but a few of the approximately 60 North American species to Conasellus probably over-

\footnotetext{
* Department of Invertebrate Zoology, National Museum of Natural History, Smithsonian
} Institution, Washington, D.C. 20560, U.S.A. 
simplifies the situation. But until enough taxonomic information is accumulated to permit a soundly based generic reassessment, I will follow the French authors. However, in place of Conasellus Stammer (1932) I am using its senior synonym, Caecidotea Packard (1871). For many years American authors assigned their blind species from subterranean waters to Caecidotea and their epigean species to Asellus. Miller (1933) presented evidence that the species of Caecidotea must have evolved independently a number of times from epigean species, and proposed reducing Caecidotea to a synonym of Asellus, as had been advocated by Forbes (1876) and Chappuis (1927). Mackin and Hubricht (1940) supported the independent status of Caecidotea, and Collinge (1945) went so far as to recognize separate subfamilies, Asellinae and Caecidotinae, but most specialists have supported Miller's position (Chappuis, 1950, 1953, 1957; Birstein, 1951; Steeves, 1963; Vandel, 1964). I agree with the latter authors, but in accordance with the law of priority use Caecidotea in place of Conasellus. Henry and Magniez (1970) pointed out the seniority of Caecidotea, but nevertheless usec Conasellus, saying, ,Nous laissons donc aux systématiciens du Nouveau-Monde le soin de règler ce point de la nomenclature".

\section{Caecidotea chiapas, new species (Figures 1 - 39)}

Material examined. Chiapas Mexico: - Cueva de los Murciélagos, $15 \mathrm{~km}$ ESE of San Cristobal de las Casas, collected by J. Cooke, W. Russell, and R. Mitchell, 29 VIII 1972: 6 ठ0 $(7.7,6.6,6.4,6.2,6.2,5.2 \mathrm{~mm}), 5$ ovigerous 9 ( $(5.5,5.2,5.0,4.7$, $4.6 \mathrm{~mm}$ ), 7 mancas (largest $1.6 \mathrm{~mm}$ ). - Cueva de los Llanos, $15 \mathrm{~km}$ ESE of San Cristobal de las Casas, collected by J. Cooke, W. Russell, R. Mitchell, 29 VIII 1972: 2 ठ大 $(7.5,6.0 \mathrm{~mm}), 3$ ovigerous $\$ ?(6.0,5.6,4.6 \mathrm{~mm}), 2$ immature $\$ ?(4.8,4.5 \mathrm{~mm})$.

The 7.7-mm of from Cueva de los Murciélogos is the holotype, USNM 152766; the remaining specimens are paratypes.

Description. Small, eyeless, unpigmented. Length up to at least $7.7 \mathrm{~mm}$; body slender, linear, about 3.8 times as long as wide; coxae all visible in dorsal view. Margins of head, pereonites, and telson moderately setose. Head twice as wide as long; anterior margin slightly concave, without rostrum; postmandibular lobes broadly rounded. Telson slightly longer than wide; sides subparallel; caudomedial lobe rather low and broad, not sharply delimited.

Antenna 1 reaching middle of last segment of antenna 2 peduncle; flagellum of 5 - 7 segments; last 3 segments each bearing esthete. Antenna 2 reaching pereonite 5; last segment of peduncle about 1.6 times length of preceding segment; flagellum of 25 - 35 segments.

Mandibles with 4-cuspate incisors and lacinia mobilis; spine row with 10 spines in left mandible, 12 spines in right mandible. Palp as in fig. 14. Maxilla 1, apex of outer lobe with 13 robust spines and 1 subterminal seta; inner lobe with 5 apical plumose setae. Maxilliped with 5 - 6 retinaculae.

0 pereopod 1 propus about 1.5 times as long as wide; palm defined proximally by 3 robust spines, median process of palm triangular, separated from smaller rounded distal process by U-shaped cleft. Dactyl flexor margin with rounded boss proximally and about 4 weak spines distally. $\$$ pereopod 1 propus more slender, about 


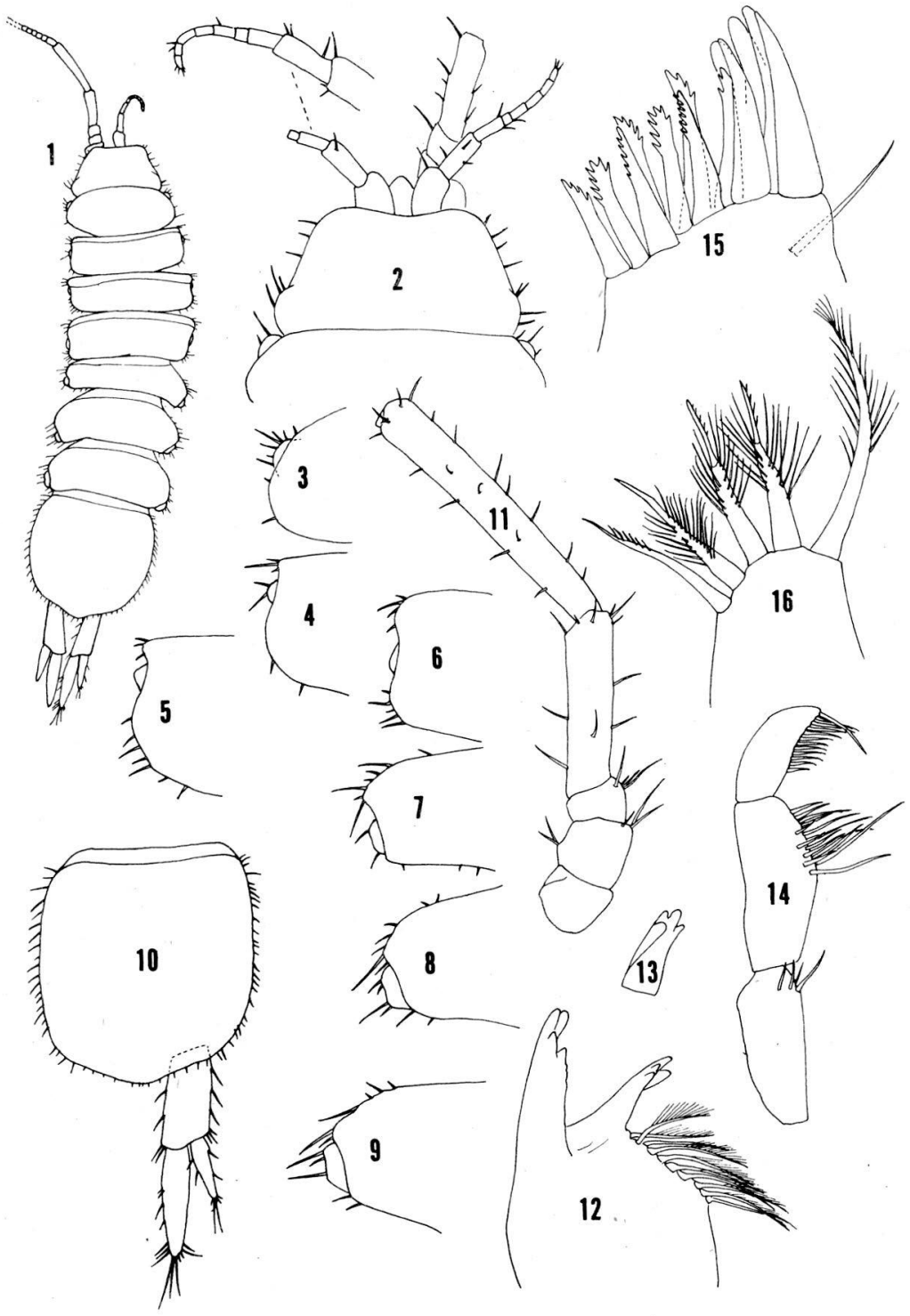

Figs. 1-16.

Caecidotea chiapas. $1, \delta$, dorsal; 2,9 head, dorsal; 3-9, lateral parts of pereonites 1-7, dorsal; 10, telson and uropod, dorsal; 11, of left antenna 2, dorsal; 12, left mandible; 13, incisor of right mandible; 14 , right mandibular palp; 15 , maxilla 1 , outer lobe; 16 , maxilla 1 , inner lobe. 


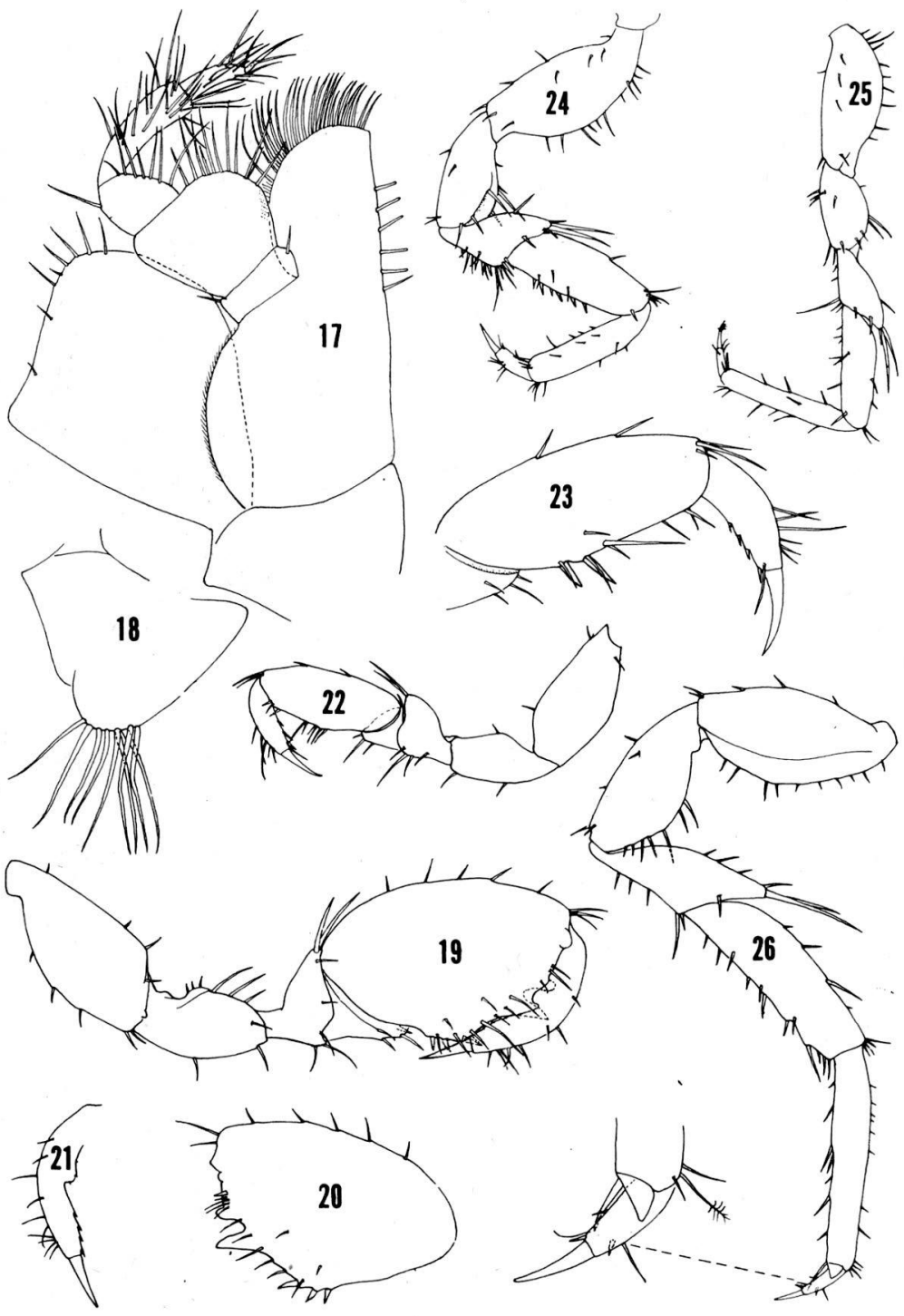

Figs. 17-26.

Caecidotea chiapas. $17, q$ maxilliped; 18 , oostegite of $\$$ maxilliped; 19 , d pereopod 1, lateral; 20 , ô pereopod 1 propus, medial; 21 , ơ pereopod 1 dactyl, medial; $22, q$ pereopod 1 , medial; 23 , propus and dactyl of $q$ pereopod 1 , lateral; 24 , ot pereopod $4 ; 25$, + pereopod $4 ; 26, \delta$ pereopod 6. 


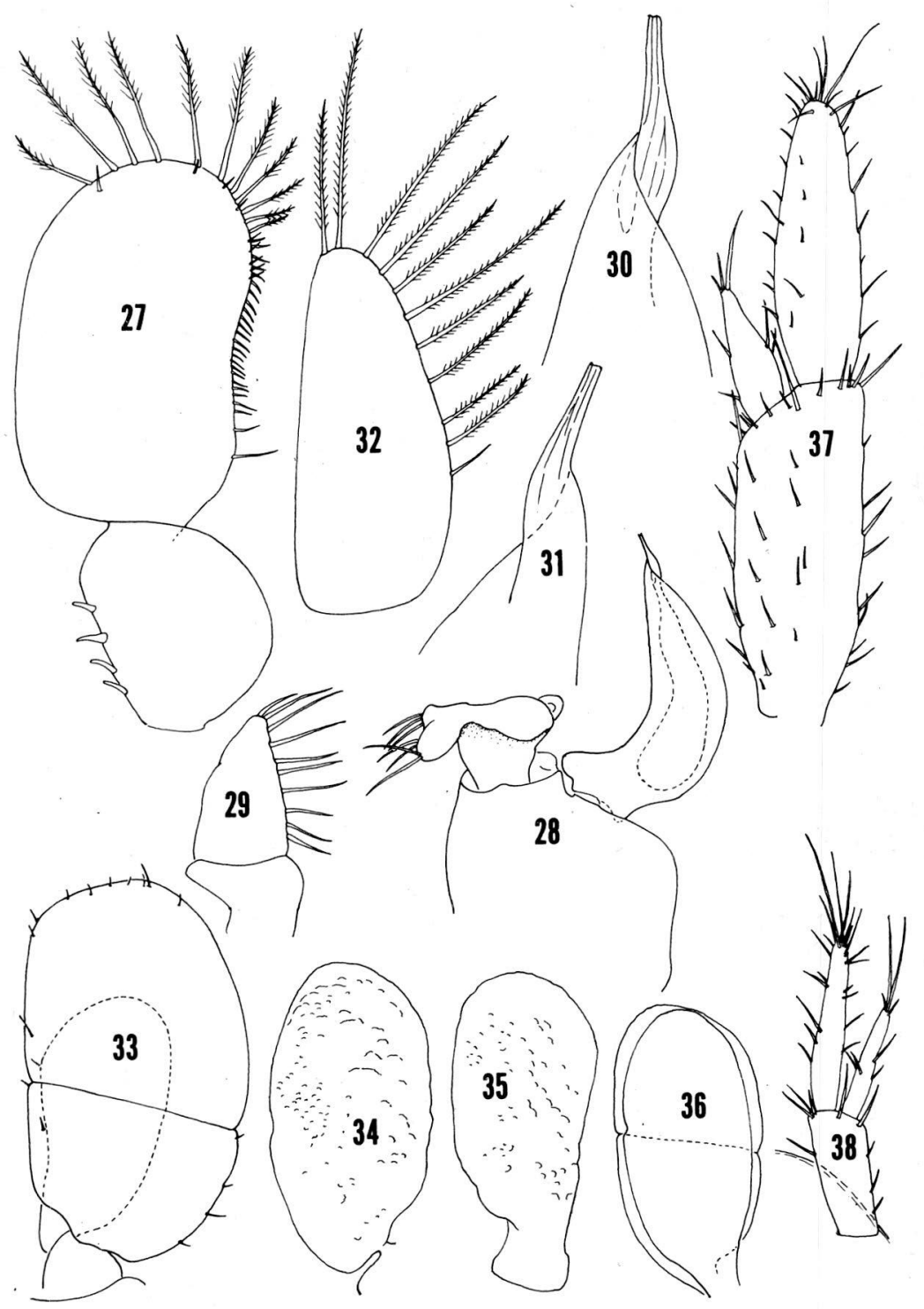

Figs. 27-38.

Caecidotea chiapas. 27, ठే pleopod 1, anterior; 28, ठే pleopod 2, posterior; 29, ठే pleopod 2 exopod, flattened under cover glass; 30 , ot right pleopod 2 endopod tip, posterior; 31 , same, anterior; 32 , + pleopod 2 , anterior; 33 , o pleopod $3 ; 34$, o pleopod 4, exopod; 35 , same, endopod; 36 , ơ pleopod $5 ; 37$, ơ uropod, dorsal; 38,9 uropod, ventral. 
2.5 times as long as wide; palm with $0-2$ proximal spines, medial and distal processes absent; dactyl without proximal boss. Pereopod 4 more robust in $\delta$ than in \%; merus and carpus with more spinose flexor margins.

to pleopod 1 larger than pleopod 2; protopod about 0.6 length of exopod, with 4 retinaculae. Exopod about 0.6 as wide as long, with plumose setae on distal margin and short naked setules on concave lateral margin. $\delta$ pleopod 2 exopod bent anterolaterally, shape when flattened triangular, with long setae on lateral margin. Endopod slender, curving laterally and tapering distally; tip (cannula) twisted clockwise, without additional processes. + pleopod 2 oval, about 2.4 times as long as wide, with about 10 plumose setae on distal and lateral margins. Pleopod 3 exopod about 1.8 times as long as wide; distal segment about 1.5 times length of proximal segment; marginal setae short, sparse, non-plumose. Pleopods 4 and 5 rather fleshy, without marginal setae; exopod of pleopod 5 with poorly defined transverse suture. Uropods as in figs. 37-38, varying with age and sex; exopod broader in large $\$ 0 \%$

Etymology. The new species is named for the Mexican state of Chiapas.

Relationships. Caecidotea chiapas is closest geographically and apparently also morphologically to the recently described C. pasquinii (Argano, 1972) from Veracruz state, Mexico, but differs in a number of characters including the following: Left mandible, lacinia 4-cuspate rather than 3-cuspate. Maxilla 1 outer lobe with 13 rather than 11 apical spines.

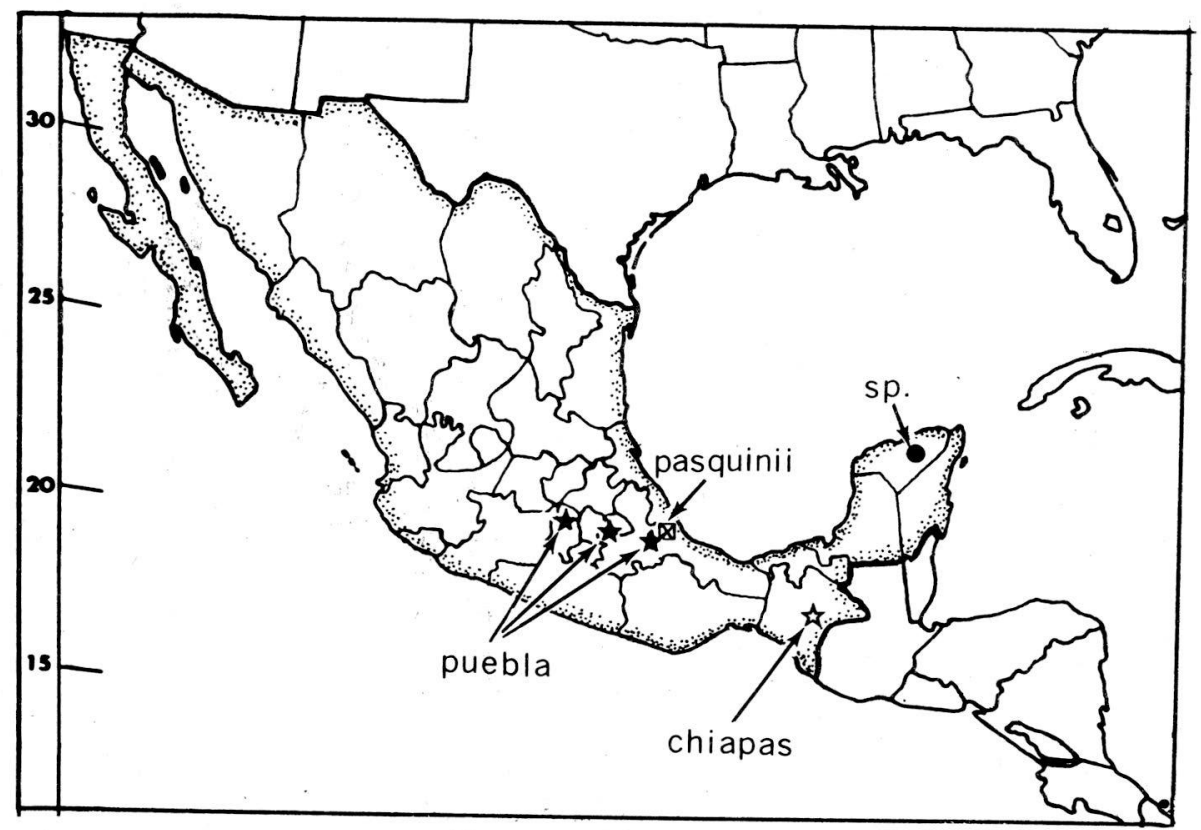

Fig. 39.

Known occurrences of Caecidotea spp. in Mexico. 
$\delta$ pereopod 1, palm of propus with 2 processes rather than 1 . Pereopod 4 with greater sexual dimorphism. $\delta$ pleopod 1 with more concave lateral margin armed with short setae. $\delta^{*}$ pleopod 2 with more curved endoped and long twisted rather than short straight cannula; exopod triangular rather than oval. Uropod with relatively shorter protopod.

Distribution of Caecidotea in Mexico. The reported occurrences of Caecidotea in Mexico are shown in fig. 39. C. puebla (Cole and Minkley, 1968) the only known epigean species, is considered by Fleming (1973) to be identical with $C$. communis (Say), an inhabitant of the northeastern United States. Disjunct populations of $C$. communis in several Colorado lakes and in Echo Lake, Washington, may have been introduced by man, and its possible artificial introduction into Mexico merits investigation. If Fleming is correct, the occurrence of an isolated Mexican population of C. communis is difficult to explain otherwise.

The record of Caecidotea in Yucatan is based on Creaser's (1938) report of a single incomplete female from Balam Canche Cave near Chichen Itza.

C. chiapas extends the known range of New World Asellidae nearly to the southern boundary of Mexico. Thus far no asellids have been reported from Central or South America.

Caecidotea sequoiae, new species (Figures 40 - 59)

Material examined. California, Tulare Co., Sequoia National Park: Liburn Cave, collected by Steven J. Shimek and Paul Hara, 13 X 1974: 1 o (5.3 mm, holotype, USNM 152769), 1 (3.3 mm, paratype, USNM 152770).

Description. Small, eyeless, unpigmented. Length up to at least $5.3 \mathrm{~mm}$; body slender, linear, about 5.3 times as long as wide; coxae all visible in dorsal view. Margins of head, pereonites, and telson setose; dorsal surfaces with scattered setae. Head slightly more than twice as wide as long; anterior margin slightly concave, without rostrum; postmandibular lobes broadly rounded. Pleonites 1 and 2 clearly visible, not much narrower than telson. Telson linguiform, about 2.6 times as long as wide; caudomedial lobe scarcely delimited.

Antenna 1 reaching distal 5 th of last segment of antenna 2 peduncle; flagellum of 10 segments in holotype, 7 segments in paratype; last 2 segments each bearing esthete. Antenna 2 reaching posterior margin of pereonite 6; last segment of peduncle about 1.6 times long as preceding segment; flagellum of 43 segments in holotype, 23 segments in paratype.

Right mandible with 4-cuspate incisor; spine row with 8 spines; palp as in fig. 44 . Left mandible not examined. Maxilla 1, apex of outer lobe with 11 robust spines and 2 subterminal setae; inner lobe with 5 apical plumose setae.

Pereopod 1 propus about twice as long as wide; palm without processes, defined by 2 robust spines; flexor margin of dactyl with 3 spines. Pereopods $2-7$, dactyl with accessory claw above and slightly behind main claw.

ot pleopod 1 larger than pleopod 2; protopod about $1 / 4$ length of exopod, with 4 retinaculae. Exopod about twice as long as wide, with about 10 widely spaced setae on medial and distal margins and numerous close-set setae on slightly concave lateral margin, decreasing in length toward midlength of margin. 


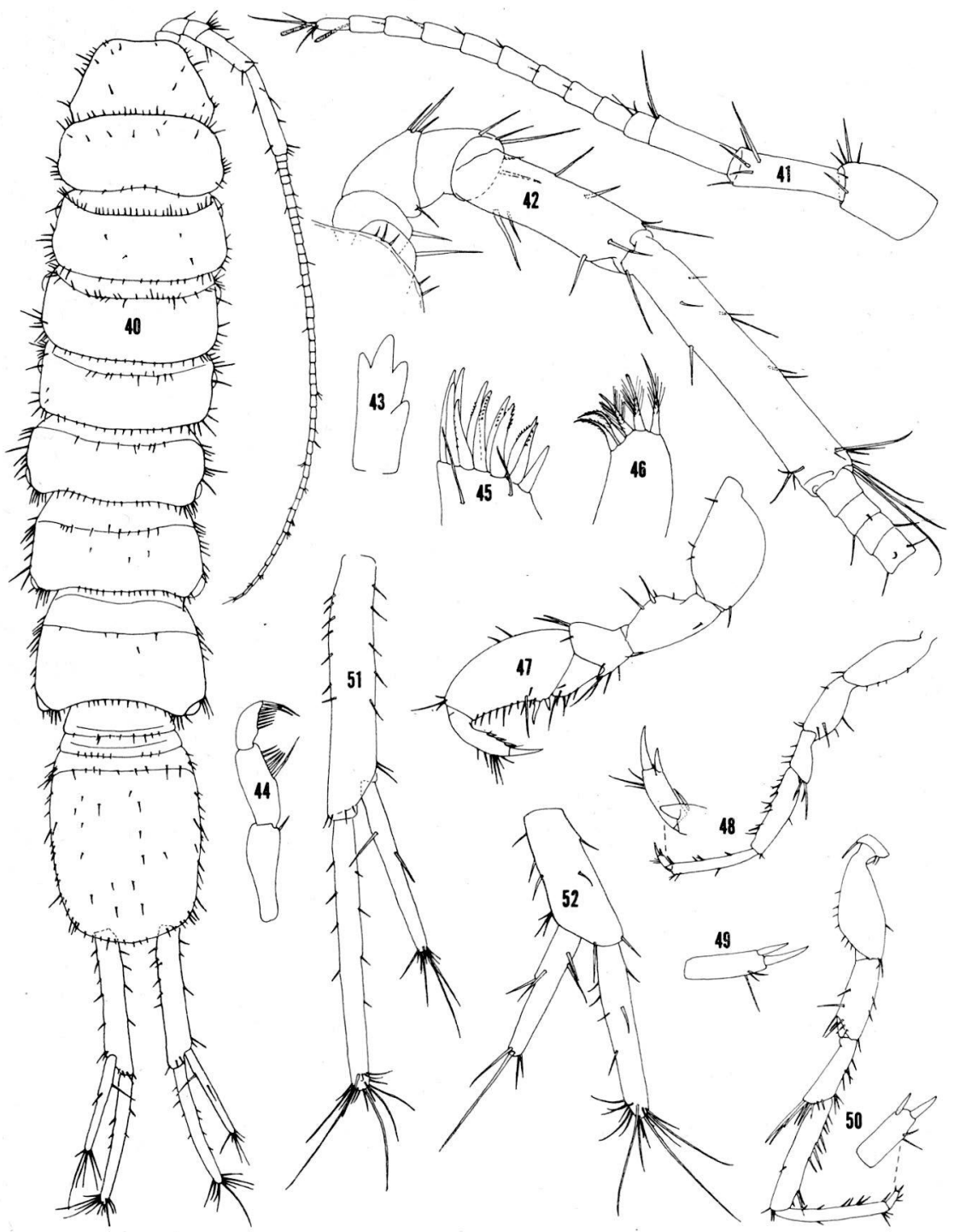

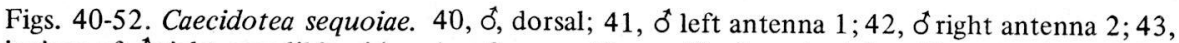
incisor of 0 right mandible; 44 , palp of same; 45 , maxilla 1 , outer lobe; 46, same, inner lobe; 47 , ô pereopod 1 , lateral; 48 , pereopod 3 , lateral; 49 , dactyl of pereopod 6 , lateral; 50 , pereopod 7, lateral; 51, ô right uropod, dorsal; 52, $\uparrow$ left uropod, dorsal. 


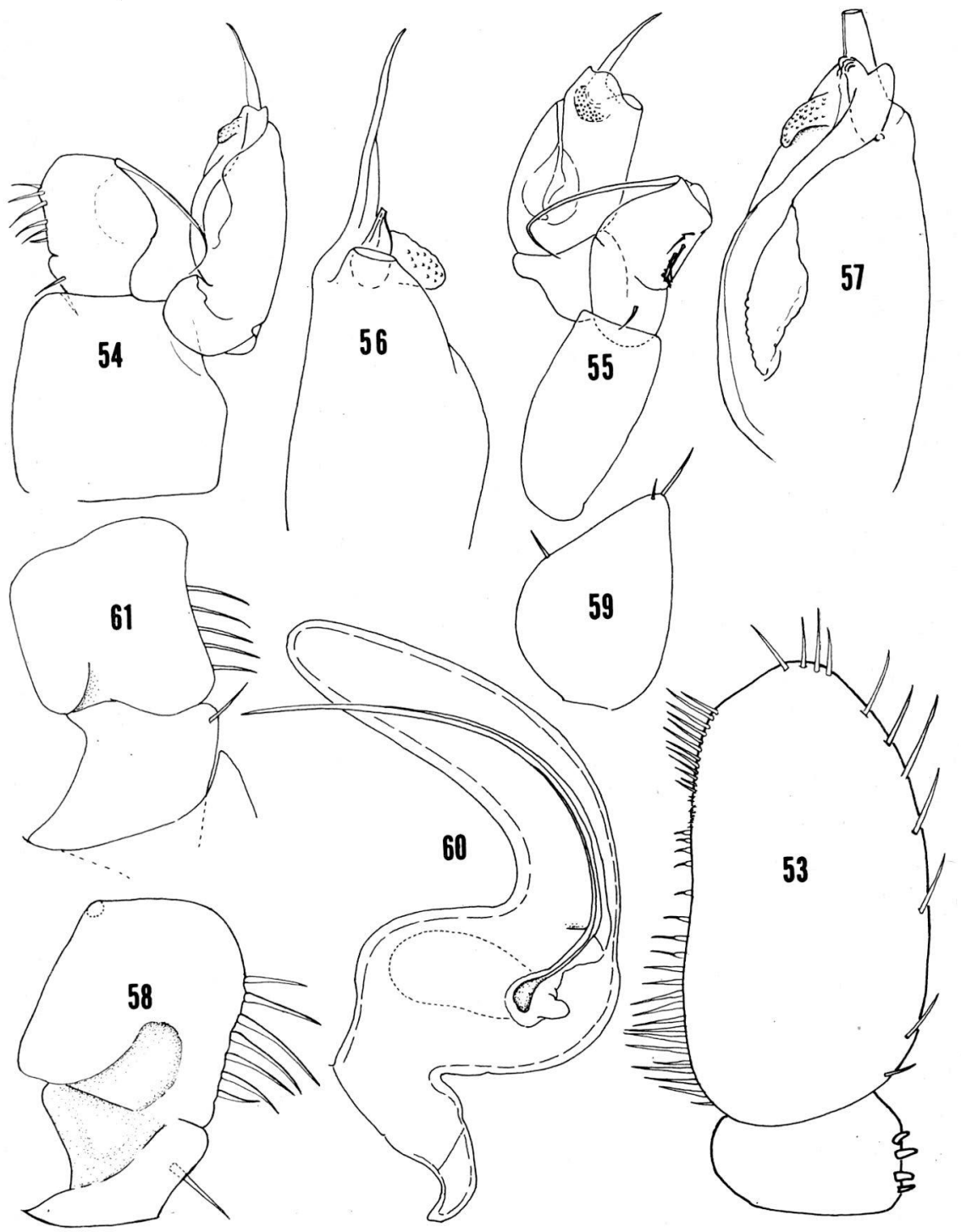

Figs. 53-59.

Caecidotea sequoiae. 53, ơ pleopod 1, anterior; 54, ơ pleopod 2, anterior; 55, ठtright pleopod 2 , lateral; 56, endopod tip, ठ́ pleopod 2, posterior; 57, same, anterior; 58, ठ pleopod 2 exopod, posterior; 59, 9 left pleopod 2, anterior. 60-61, Asellus californicus. 60, ơ left pleopod 2 endopod, anterior (slightly tilted); 61, ó pleopod 2 exopod, posterior. 
t pleopod 2 protopod slightly wider than long, unarmed. Exopod much shorter than endopod, suture between segments not clearly defined; proximal segments with 1 seta on lateral margin and triangular concavity on posterior surface; distal segment quadrate; lateral margin with 7 setae; posterolateral corner with long, curved setae. Endopod subpyriform, with long fissure; tip with the following elements for which I am using the standard terms introduced by Steeves, altho I consider the homologies questionable: Cannula short, conical; medial process very long, spiniform; lateral process a papillate ridge; posterior process cylindriform, truncate.

o pleopod 2 pyriform, with 2 setae at apex and 1 seta on lateral margin.

Uropods slender, slightly longer than pleotelson. Endopod 1.5 (holotype) or 1.3 (paratype) times as long as exopod; both rami with dense ćluster of long apical setae.

Etymology. The specific name refers to the occurrence of the new species in Sequoia National Park.

Relationships. The slender body, elongate telson, and long antenna 2 and uropods are features common to a number of other troglobitic species of Caecidotea. The accessory claws on the dactyls of pereopods $5-7$ are unusual, and the structure of the endopod of the male pleopod 2 is unlike that of any known asellid.

\section{Asellus (Phreatoasellus) californicus (Miller) (Figures 60 - 61)}

Asellus californicus Miller, 1933, pp.97-99, figs. 1-14. - Miller and Hoy, 1939, passim. Caecidotea californicus (Miller). - Van Name, 1936, pp. 521-522, fig. 323; 1940 p. 133.

Asellus kalifornicus Miller. - Chappuis, 1955, p. 165.

Material examined: California, Lake Co., near Kelseyville; from renovated well on ranch of William Tuttle, collected by E.O. Essig, 21 III 1931: 3 syntypes, 2 ơ USNM 134486 and 134488, 1 \& USNM 134487. - California, Santa Clara Co.; SW of Los Gatos, springs of Black Creek on slope of Black Mountain, collected by Roman Kenk, 25 VI 1967: 10+ ơ, USNM 112827. - California, Napa Co., Napa; mouth of spring under house, collected by S. Gray, III 1969: 3 c, USNM 135742.

Miller did not designate any types for Asellus californicus, hence the specimens examined by him are syntypes. In August 1970 Miller deposited 3 specimens in the National Museum of Natural History, designating them as $\delta^{*}$ holotype, $q$ allotype, and $\delta$ paratype. However, according to Article 73 of the International Code, these 3 specimens are syntypes.

The species has until now been known only from the type-locality; the present records extend the known range about 130 miles south. Miller provided a detailed description and full illustrations, and I add here only some details of the of pleopod 2 , since the taxonomic importance of this appendage was not fully recognized in 1933.

Miller describes the endopod of the o pleopod 2 as "bulbous at the base, tapering into a long cylindrical process which curves outward over exopod. A fine 
needle-like stylet originates in bulbous part, runs up through a sheath in curved process, and protrudes beyond its tip". As suggested by Miller's fig. 2, the bulbous base contains a cavity which opens on the anterior surface by a fissure which continues into the stylet. A smoothly rounded labial spur (Bowman and Holmquist, 1975) is present on the proximal margin of the fissure. The stylet in the Napa and Los Gatos specimens is free from the curved cylindrical process and not enclosed in a sheath. Steeves (1963) interprets the stylet as a very long cannula and the curved cylindrical process as a caudal process. The exopod of the $\delta$ pleopod 2 has a well developed catch-lobe on the posterior surface of the distal segment.

A. californicus is assigned to the genus Asellus because of the prominent basal and labial spurs on the endopod and the catch-lobe on the exopod of the of pleopod 2. Within Asellus it is excluded from the subgenus Asellus because the maxilla 1 inner lobe has 5 rather than 4 terminal setae, the $\delta$ pereopod 1 palm lacks a proximal boss, and the $q$ pleopod 2 is not medially expanded. The distinctions between the other 2 subgenera of Asellus, Mesoasellus Birstein (1939) and Phreatoasellus Matsumoto (1962) are based on body shape and proportions. Both species of Mesoasellus, A. (M.) dybowskii Semenkevich from Lake Baikal and A. (M.) strinatii Chappuis from Turkey, are epigean broad-bodied forms, whereas the 5 Japanese species of Phreatoasellus, like A. californicus, are troglobitic and slender. Since Miller (1933) showed a clear correlation between a slender body and a subterranean life in asellids, the criteria used to separate the 2 subgenera seem questionable. Since I have not had the opportunity of examining specimens of Mesoasellus or Phreatoasellus I am assigning A. californicus provisionally to Phreatoasellus.

Except $A$. (P.) californicus, the species of Phreatoasellus are limited to Japan. The relationship of $A$. californicus to Eurasian rather than to other North American asellids has been noted by Birstein (1951) and by Henry and Magniez (1970), but the latter authors suggested affinities with certain species of Nipponasellus. The 1-merous mandibular palp of Nipponasellus makes this suggestion unlikely. If I am correct in assigning $A$. californicus to Phreatoasellus, there must have existed in the past a species or group of species ancestral to both $A$. californicus and its Japanese relatives, extending from Japan to California, presumably by way of the Bering land bridge. Because of the low vagility of troglobites, the ancestral form was probably epigean.

\section{Salmasellus, new genus}

Diagnosis. Body elongate. Pereonites nearly uniform in width. Telson not elongate. Mandibular palp 3-merous. Maxilla 1 inner lobe with 5 apical setae. o pereopod 1 propus long, slender; palm without bosses, armed with row of strong spines. Dactyls of pereopods 2-7 without accessory spines. Endopod of $\delta$ pleopod 2 without basal or labial spurs; lateral margin with long setae arising from inflated base and fitting into groove along margin. Exopod of $\delta$ pleopod 2 without catch-lobe. Pleopod 3 exopod with transverse suture.

Type-species. Salmasellus steganothrix, new species.

Etymology. From the Latin "Salmo" = trout, + Asellus, referring to the disco very of this isopod in stomachs of rainbow trout. 
Remarks. It is with some misgiving that I propose a new genus based on imperfect specimens removed from fish stomachs. I am encouraged to do so because of the abundance of the fragments and the distinctiveness of the new isopod; otherwise I might have been deterred by Stebbing's (1888) comment on an amphipod described by Stimpson (1857) from the stomach of a salmon: "Corophium salmonis, which Stimpson took, 'not in a very good state of preservation,' out of the stomach of a salmon, had almost better have been left there, instead of being drawn forth to create a very indistinct species."

\section{Salmasellus steganothrix, ne'w species (Figures 62 - 84)}

Material examined. Alberta, Canada, Jasper National Park, Horseshoe Lake, collected by R. Stewart Anderson, numerous incomplete specimens and fragments, from stomachs of rainbow trout. An imperfect $\delta, 7.3 \mathrm{~mm}$, has been selected as the holotype, USNM 152771.

Description. Eyeless, unpigmented. Length up to about $8 \mathrm{~mm}$; body slender, about 3.8 times as long as wide; pereonites increasing gradually in width to pereonite 6; pereonite 7 slightly narrower. Coxae all visible in dorsal view. Margins of head, pereonites, and telson moderately spinose. Head about twice as wide as long; anterior margin with distinct rostrum, postmandibular lobes prominent. Telson slightly wider than long; lateral margins convex, caudomedial lobe well defined.

Antenna 1 about as long as width of head, flagellum of $4-5$ segments, last 3 seg ments each with esthete. Antenna 2 broken on all specimens, usually between $\mathrm{p}$ duncle segments 3 and $4 ; 2$ of longest antennae found among fragments had 53 ana 55 flagellar segments and measured 7.5 and $6.2 \mathrm{~mm}$ respectively, hence antennae must be nearly as long as body.

Incisor of left mandible 5-cuspate; lacinia mobilis and incisor of right mandible 4-cuspate. Spine row with 17 spines in right mandible, 16 in left mandible. Palp as in fig. 66; 3rd segment with 16 setae in both mandibles. Maxilla 1, apex of outer lobe with 13 robust spines and 3 subterminal setae; inner lobe with 5 apical plumose setae ( 1 specimen had 7 setae on right maxilla 1 and 5 on left). Maxilliped with 3 retinaculae.

$\delta$ pereopod 1 propus about 3 times as long as wide; palm straight, without processes but with about 8 strong sharp spines on proximal 0.6. Dactyl flexor margins with about 9 spines. 9 pereopod 1 similar in shape to that of $\delta$, but much smaller and more poorly armed. Perepods 2-7 long, slender, and rather heavily spinose.

$\delta$ pleopod 1 larger than pleopod 2; protopod about 0.4 length of exopod, with 3-4 retinaculae. Exopod nearly twice as long as wide, with about 25 short non-plumose setae on apical margin and distal part of lateral margin.

$\delta$ pleopod 2 protopod slightly wider than long, with 1 seta on medial margin. Exopod much shorter than endopod, bent obliquely toward endopod; proximal segment subtriangular, with 5-7 plumose setae on lateral margin; distal segment oval, with concavity on proximolateral part of posterior margin and 2 long curved plumose setae at apex. Exopod L-shaped; base of L bearing 2 or 3 long setae increasing in length medially, fitting into groove on lateral surface of upright part of $\mathrm{L}$, 


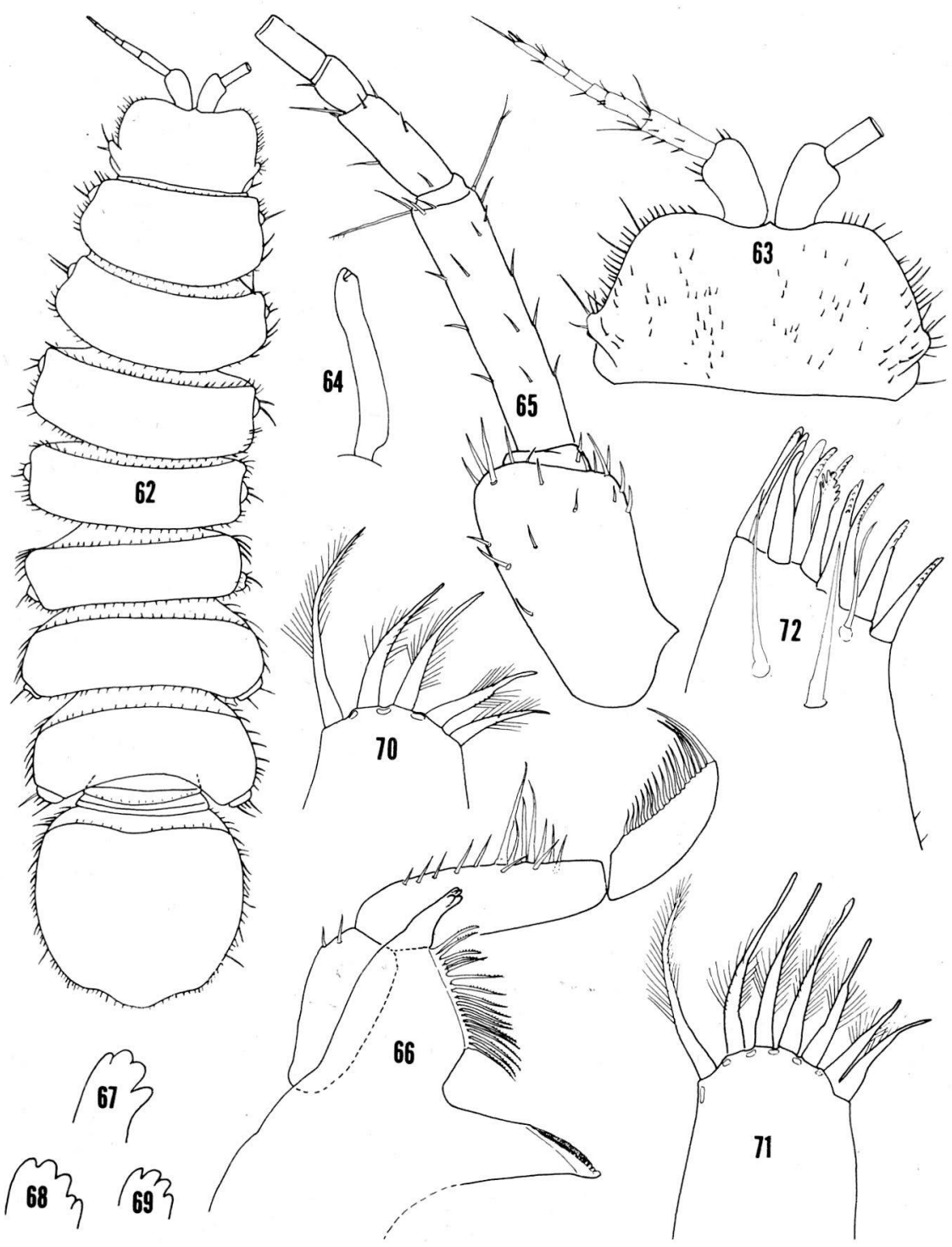

Figs. 62-72. Salmasellus steganothrix. 62, 9 , dorsal; 63, head, dorsal; 64, left penis, ventral; 65 , of right antenna 1 , dorsal; 66 , right mandible; 67 , incisor of right mandible; 68 , incisor of left mandible; 69, lacinia of left mandible; 70, maxilla 1 , inner lobe; 71 , same, with abnormal number of setae; 72 , maxilla 1 , outer lobe. 
352

THOMAS E. BOWMAN

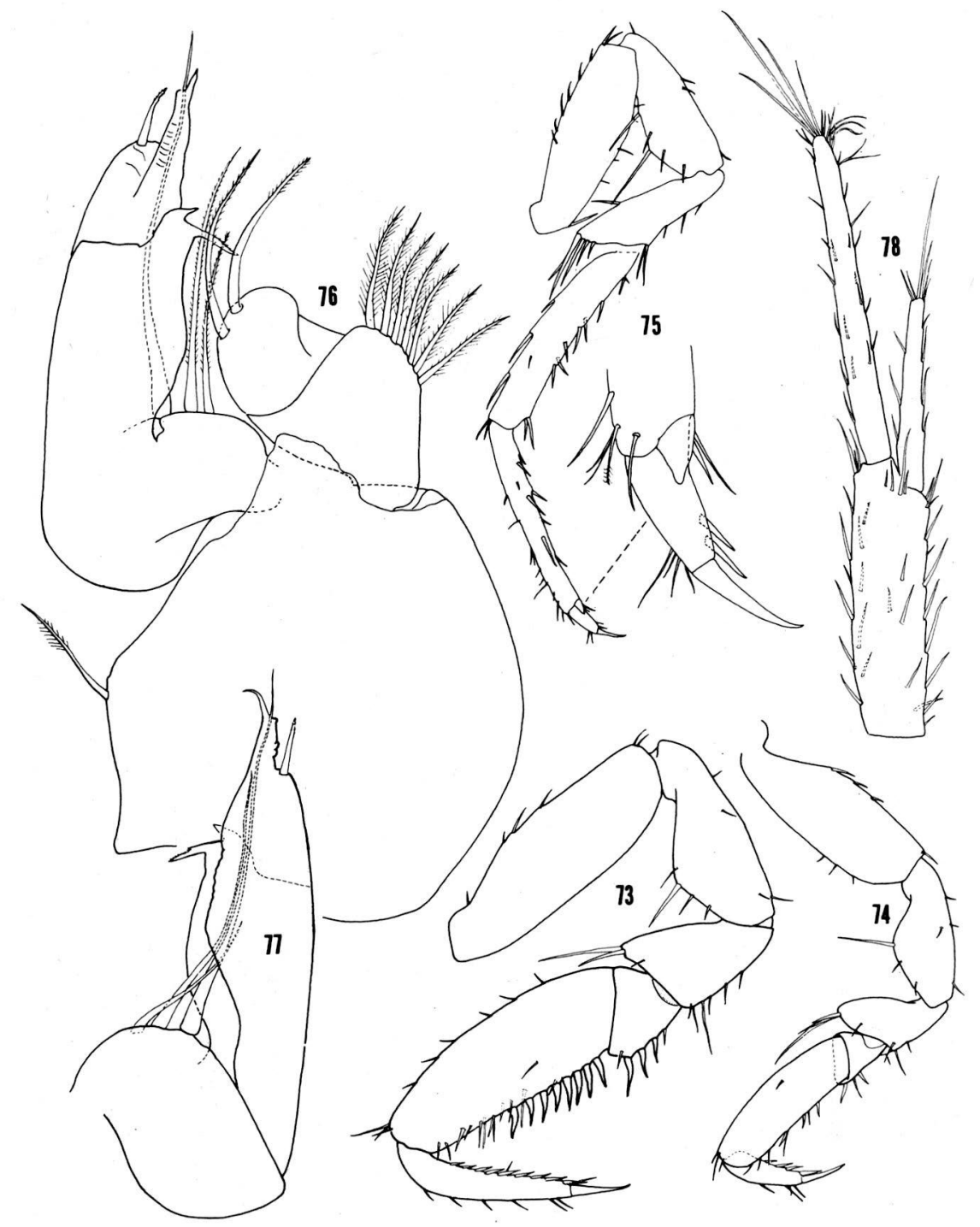

Figs. 73-78. Salmasellus steganothrix. 73 , o pereopod $1 ; 74,9$ pereopod $1 ; 75$, pereopod 6 ; 76 , ठ pleopod 2, posterior; 77, ठో pleopod 2 endopod, anterior; 78, uropod. 
longest seta protruding from apex of upright, giving appearance of short apical seta. Upright part with transverse suture on posterior surface distal to midlength; suture leading to medial process ending in 2 divergent sharp tines; distal tine shorter, smooth; proximal tine longer, with serrate distal margin. Anterior surface of upright part without suture or medial process, more excavated proximally than posterior surface, leaving bases of 2-3 setae more exposed anteriorly than posteriorly.

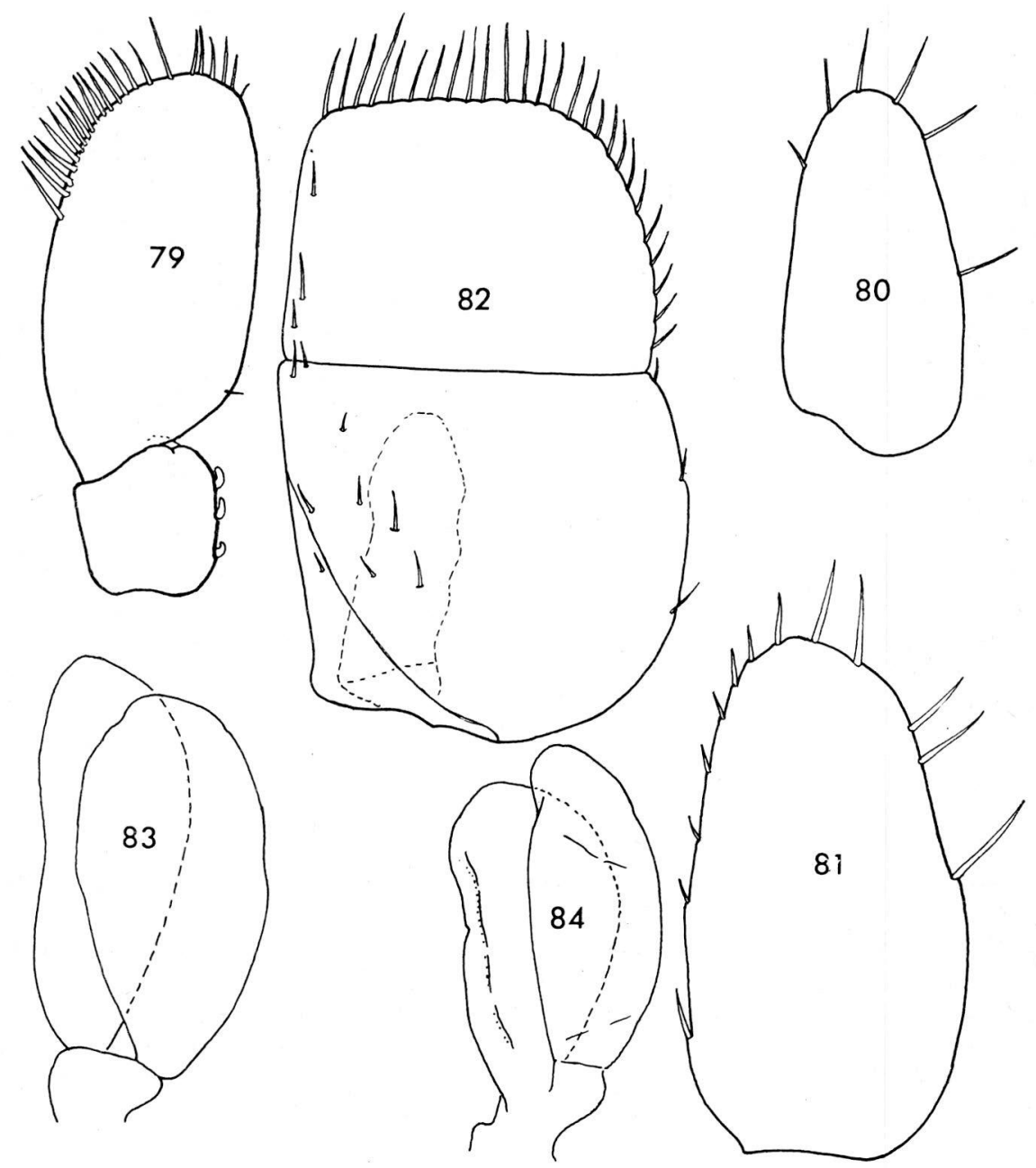

Figs. 79-84. Salmasellus steganothrix. 79, ơ pleopod $1 ; 80-81$, $\$$ right pleopod 2 , anterior, from different specimens; 82 , $\$$ pleopod 3 , anterior; 83 , ơ pleopod 4 , anterior; 84 , ơ pleopod 5 , anterior. 
Apex of upright ending in rugose cylinder with slender curved tip; spiniform seta inserted on shoulder near base of cylinder in some specimens, absent in others.

$\$$ pleopod 2 oval, margins sparsely armed with naked setae, those on medial margin shorter and absent in small specimens.

Pleopod 3 exopod linguiform, bout 0.6 as wide as long; proximal segment about 0.7 length of distal segment. Pleopods 4 and 5 small, fleshy, without marginal setae or clearly defined sutures.

Uropods detached from all specimens, largest uropod found about $2.6 \mathrm{~mm}$ in length. Protopod with long spines on margins and surfaces. Rami slender, with long terminal setal clusters; exopod about 0.7 , endopod about 1.2 times length of protopod.

Etymology. The specific name, from the Greek "stegano" = covered and "thrix" $=$ hair, refers to the covering of the setae of the endopod of the $\delta$ pleopod 2 by the walls of the lateral groove.

Ecology. Some physical and biological data for Horseshoe Lake are given by Anderson (1974, table 6). This lake; at an elevation of $1230 \mathrm{~m}$, has an area of 13 hectares and a maximum known depth of $32 \mathrm{~m}$. The maximum Secchi disk reading was $12 \mathrm{~m}$. In plankton samples Anderson found 6 species of Cladocera and 4 copepods: Diaptomus silicis, Eucyclops agilis, Acanthocyclops vernalis, and Microcyclops varicans rubellus. To avoid possible confusion, attention is called to the existence of another Horseshoe Lake in Banff National Park, farther south in Alberta (Anderson, 1974, table 4).

The absence of eyes and body pigment suggest that Salmasellus inhabits underground waters that are connected with Horseshoe Lake by springs.

Salmasellus must have migrated to Horseshoe Lake, presumably from the south, by groundwater routes since the Pleistocene; it is inconceivable that it could have survived under the huge thickness of ice that covered the type-locality during the Pleistocene.

\section{SUMMARY}

Fleming's arguments (1973) for reducing Conasellus to a synonym of Asellus are considered inadequate, but the name Conasellus is replaced by its senior synonym Caecidotea. Two new troglobitic species of Caecidotea are described, C. chiapas from caves in Chiapas, Mexico, and C. sequoiae from Liburn Cave, Tulare County, California. Asellus californicus is reported from springs in Napa and Santa Clara Counties; the ot pleopod 2 is redescribed, and the species is assigned to the subgenus Phreatoasellus. A new genus and species, Salmasellus steganothrix, is described from Horseshoe Lake, Alberta, Canada.

\section{RESUME}

Les arguments de Fleming (1973) pour mettre en synonymie Conasellus et Asellus 
sont considérés comme inadéquats. Cependant, le nom générique Conasellus est remplacé par son synonyme antérieur Caecidotea.

Deux nouvelles espèces troglobies de Caecidotea sont décrites: $C$. chiapas provenant de cavernes à Chiapas (Mexique) et C.sequoiae de la grotte de Liburn, Comté de Tulare (Californie). Asellus californicus est signalé dans des sources des Comtés de Napa et de Santra Clara; le pléopode 2 du mâle est redécrit et l'espèce est attribuée au sous-genre Phreatoasellus. Une espèce appartenant à un nouveau genre, Salmasellus steganothrix, est décrite du lac Horshoe, Alberta (Canada).

\section{REFERENCES}

ANDERSON, R. STEWART. 1974. Crustacean plankton communities of 340 lakes and ponds in and near the national parks of the Canadian Rocky Mountains. J. Fish. Res. Bd. Canada, 31 (5): 855-869.

ARGANO, ROBERTO. 1972. An asellid of the subterranean waters of Veracruz, Mexico (Crustacea, Isopoda). Quaderni Accad. Naz. Lincei, 171: 35-42.

BIRSTEIN, J.A. 1939. Zoogeograficheskaya kharakteristika vodyanykh oslikov Baikala (Zoogeographical characterization of Baikal water-slaters). Doklady Akademii Nauk SSSR, 25 (3): 248-251.

- $\quad$ 1951. Freshwater isopods (Asellota). Fauna SSSR, Crustacea 7 (5): 1-140 [in Russian; English translation by Israel Program for Scientific Translation, 148 pp. 1964].

BOWMAN, THOMAS E. 1974. The California freshwater isopod, Asellus tomalensis, rediscovered and compared with Asellus occidentalis. Hydrobiologia, 44 (4): 431-441.

BOWMAN, THOMAS E. and CHARLOTTE HOLMQUIST. 1975.Asellus (Asellus) alaskensis, n.sp., the first Alaskan Asellus, with remarks its Asian affinities. Proc. Biol. Soc. Washington, $88(7): 59-72$.

CHAPPUIS, P.A. 1927. Die Tierwelt der unterirdischen Gewässer. Die Binnengewässer, 3, 175 pp.

1950. Campagne spéologique de C. Bolivar et R. Jeannel dans l'Amérique du Nord. Asellides. Arch. Zool. Exp. Gén., 87: 177-182.

1953. Sur la systématique du genre Asellus. Notes Biospéol. Paris, 8: 67-79.

1955. Remarques générales sur le genre Asellus et description de quatres especes nouvelles. Notes Biospéologiques, Paris, 10: 163-182.

- 1957. Un asellide nouveau de l'Amérique du Nord. Notes Biospéologiques, Paris,

12: 37-43.
COLE, GERALD A., and W.L. MINCKLEY. 1968. A new species of aquatic isopod crustacean (genus Asellus) from the Puebla Plateau, Central México. Proc. Biol. Soc. Washington, 81: 755-760.

1972. Stenasellid isopod crustaceans in the Western Hemisphere - a new genus and species from México - with a review of other North American freshwater isopod genera. Proc. Biol. Soc. Washington, 84 (39): 313-326.

COLLINGE, WALTER E. 1944. On the freshwater isopod genus Caecidotea Packard. Ann. Mag. Nat. Hist., (11) 11 (84): 815-817.

CREASER, E.P. 1938. Larger cave Crustacea of the Yucatan Peninsula. Carnegie Inst. Washington Publ. 491: 159-164.

FLEMING, LAURENCE E. 1973. The evolution of the eastern North American isopods of the genus Asellus (Crustacea: Asellidae). Part II. Int. J. Speleol. 5 (3-4): 283-310.

FORBES, S.A. 1876. List of Illinois Crustacea, with description of new species. Bull. Illinois Mus. Nat. Hist., 1: 3-25.

HENRY, JEAN-PAUL, and GUY MAGNIEZ. 1968. Sur la systématique et la biogéographie des asellides. C.R. Acad. Sci., Paris, 267: 87-89.

1970. Contribution à la systématique des asellides (Crustacea Isopoda). Ann. Spéléol., 25 (2): 335-367. 
MACKIN, J.G., and LESLIE HUBRICHT. 1940. Descriptions of 7 new species of Caecidotea (Isopoda, Asellidae) from central United States. Trans. American Microscop. Soc., 59 (3): 383-397.

MAGNIEZ, GUY. 1972. Deux Stenasellidae cavernicoles nouveaux de 1'Amérique centrale: Mexistenasellus parzefalli $n$.sp. et Mexistenasellus wilkensi $\mathrm{n}$. sp. (Crustacea Isopoda Asellota). Int. J. Speleol., 4: 19-31.

MATSUMOTO, KOICHI. 1962. Two new genera and a new subgenus of the family Asellidae of Japan. Annot. Zool. Japonenses, 35 (3): 162-169.

MILLER, MILTON A. 1933. A new blind isopod, Asellus californicus, and a revision of the subterranean asellids. Univ. California Publ. Zool., 39 (4): 97-110.

MILLER, MILTON A. and ELVIN A. HOY. 1939. Differential growth and evolution in a subterranean isopod. American Nat., 73: 347-364.

PACKARD, ALPHEUS S. 1871. The Mammoth Cave and its inhabitants. American Nat., 5: 744-761.

STAMMER, H.J. 1932. Zur Kenntniss der Verbreitung und Systematik der Gattung Asellus, insbesondere der mitteleuropäischen Arten (Isopoda). Zool. Anz., 99: 113-131.

STEBBING, T.R.R. 1888. Report on the Amphipoda collected by H.M.S. Challenger during the years 1873-76. Rep. Sc:. Res. Voyage H.M.S. Challenger, Zool. 29: i-xxiv + 1-1737, pls. 1-210.

STEEVES, HARRISON R., III. 1963. Two new troglobitic asellids from West Virginia. American Midl. Nat., 70 (2): 462-465.

STIMPSON, WILLIAM. 1857. On the Crustacea and Echinodermata of the Pacific shores oI North America. Boston J. Nat. Hist., 6 (4): 444-532, pls. 18-23.

VANDEL, A. 1964. Biospéologie - La biologie des animaux cavernicoles. 619 pp.

VAN NAME, W.G. 1936. The American land and fresh-water isopod Crustacea. Bull. American Mus. Nat. Hist., 71: 1-525.

1940. A supplement to the American Land and fresh-water isopod Crustacea. Bull. American Mus. Nat. Hist., 77: 109-142. 